\title{
Levels of Motivation as Correlates of Librarians' Task Performance in University Libraries In South - East, Nigeria
}

\author{
${ }^{1}$ Rev'd Dr Obiora C. Nwosu, ${ }^{2}$ Dr U. Ugwoegbu (PhD), ${ }^{3}$ Dr. Ifeka Okeke. \\ ${ }^{I}(P h D)-C L N$ Association Professor Head, Department of library and Information Science, Nnamdi Azikiwe \\ University, Awka, Nigeria \\ ${ }^{2}$ Madonna University, Okija, Nigeria \\ ${ }^{3}$ Nnamdi Azikiwe University, Awka
}

\begin{abstract}
This paper is on levels of motivation as correlates of librarians' task performance in university libraries in South - East, Nigeria. It is a co-relational study. Questionnaire was used for data collection. Pearson Product Moment correlation Co-efficient and t-test of correlation were used for data analysis. The librarians in the university libraries studied are poorly motivated but greater majority of them perform moderately on their tasks in the libraries because of their interest and love in librarianship. The very low positive or no relationship existing between the librarians' levels of motivation and their task performance is not significant. To get the best task performance out of all the librarians as some still need to be motivated, the university management should give all the librarians adequate motivation.
\end{abstract}

Key Words: Motivation, Librarians, Task Performance, University Libraries.

\section{Introduction}

There are many career opportunities one can choose from and study at the higher institution of learning. Career pursuit depends on one's interest and choice. This is what it should be, but the researchers many years of teaching in library schools in Nigeria revealed otherwise. Many students get admitted for courses they know little to nothing about. Background knowledge about different careers help students to make informed choices based on sensitized or evoked interest. Interest in a profession helps one to give one's best to the profession with a passion. Librarianship is a noble profession. Libraries and librarians are indispensible to a nation and institutions of learning. The Nigerian Government lists library services among the essential services in her national policy on Education (2004). Librarians must, therefore, discharge their essential professional career duties with passion and sensitivity. There seems to be a cog in the wheel. Nwamefor (2007) observed that there are insensitivity and passiveness among librarians in the South - East, Nigeria. According to Nwosu (2008) there seems to be a general non-recognition of librarians and the importance of library services they offer in Nigeria. Ike (2007) stresses that libraries are foreign to Nigerian culture, having not evolved as a response to any cultural, educational or social needs, she asserts that libraries are, therefore, not enthusiastically embraced, supported or sustained by individuals, communities or governments, Federal, States or Local.

Akor (2010) queried about the non-application of motivational techniques to make professional librarians perform their duties efficiently in Nigerian universities. He avers that some of the professional librarians outperform others at work. To achieve the desired university libraries goals and to understand much about varying performance levels of individual professional librarians, every university librarian must address the issue. This bothers on the motivation of librarians. This study, therefore, is on the levels of motivation as correlates of librarians' task performance in university libraries in South-East, Nigeria.

\section{Research Method}

This is a co-relational study.

The subjects of the study are all the librarians in the university libraries, south-East, Nigeria. Only Federal and State universities were used. The population of all the librarians in the eight university libraries in the area of study is four hundred and ninety nine. The entire population was used since the number is not very large. Questionnaire was used for data collection.

Pearson Product Moment Correlation Co-efficient and t-test of correlation were used for data analysis. In decision - making, for the seventeen questionnaire items in both motivation and task performance respectively, any librarians who scored between 17.00 and 42.33 was poorly motivated, $42.50-59.33$ was moderately motivated and $59.50-68.00$ was well motivated. Any librarian who scored between 17.00 and 42.33 was of low performance, $42.50-59.33$ was of average performance, while $59.50-68.00$ was of high performance. 
III. Result

Table 1: range of scores of the librarians on their motivation

\begin{tabular}{|lcc|}
\hline $\begin{array}{l}\text { Range of scores } \\
\text { on motivation }\end{array}$ & $\mathrm{N}$ & level of motivation \\
\hline $17.00-42.33$ & 183 & Poorly motivated \\
$42.50-59.33$ & 197 & Moderately motivated \\
$59.50-68.00$ & 119 & Highly motivated \\
\hline Total & 499 & \\
\hline
\end{tabular}

Table 1 shows that out of the 499 librarians, 119 were highly motivated, 197 were moderately motivated and 183 were poorly motivated.

Table 2: Range of scores of the librarians on their Task Performance

\begin{tabular}{|c|c|c|}
\hline \multicolumn{2}{|c|}{$\begin{array}{l}\text { Range of scores on } \mathrm{N} \\
\text { Task Performance }\end{array}$} & $\begin{array}{l}\text { Level of Task } \\
\text { Performance }\end{array}$ \\
\hline $17.00-42.33$ & 119 & $\begin{array}{l}\text { low task } \\
\text { performance }\end{array}$ \\
\hline $42.50-59.33$ & 180 & $\begin{array}{l}\text { Moderate task } \\
\text { performance }\end{array}$ \\
\hline $59.50-68.00$ & 200 & High task performance \\
\hline Total & 499 & \\
\hline
\end{tabular}

Table 2 above show that 119 out of the 499 librarians in the university libraries under study have low task performance, while 180 and 200 have moderate and high performance respectively

To determine the relationship existing between the librarians' levels of motivation and their task performance, Pearson Product Moment Correlation Co-efficient (Pearson r) was used for the data analysis.

Table 3: Pearson $r$ of the librarians' motivation and their Task Performance

\begin{tabular}{|llcc|}
\hline \multicolumn{3}{|c|}{ Motivation } & Task \\
& & \multicolumn{2}{c|}{ Performance } \\
\hline Motivation & $\begin{array}{c}\text { Pearson } \\
\text { Correlation }\end{array}$ & 1 & 0.04 \\
& $\mathrm{~N}$ & 499 & 499 \\
Task & $\begin{array}{c}\text { Pearson } \\
\text { Performance Correlation }\end{array}$ & 0.04 & 1 \\
& $\mathrm{~N}$ & 499 & 499 \\
\hline
\end{tabular}

Table 3: above indicates that with the result of 0.04 of the Pearson $r$, there is a very low positive or no relationship existing between the librarians motivation and their task performance.

To determine the level of significance, t-test of correlation on the librarians' motivation and their task performance was done.

Table 4: t-test of correlation on the librarians' motivation and their task Performance

\begin{tabular}{|lrrrrrrr|}
\hline $\begin{array}{l}\text { Source of } \\
\text { variation }\end{array}$ & $\mathrm{N}$ & $\mathrm{r}$ & $\mathrm{df}$ & cal.t & crit.t & $\mathrm{P} \geq 0.05$ & \\
& 499 & 0.04 & 497 & 0.89 & 1.96 & NS \\
\hline
\end{tabular}

Table 4 above reveals that at 0.05 level of significance and 497 degree of freedom on $\mathrm{r} 0.04$, the calculated $\mathrm{t}$ 0.89 is less than the critical 1.96. The very low or no relationship existing between the librarians' motivation and their task performance is, therefore, no significant.

\section{Summary of the Findings}

From the data analysis, the following findings were made:

1. Majority of the librarians in the university libraries indicated that they were either well or moderately motivated.

2. Majority of them also perform their task well or moderately.

3. There is a very low positive or no relationship existing between the librarians' levels of motivation and their task performance is not significant. 


\section{Discussion}

Majority of the librarians indicated that they were being poorly motivated, while very few of them reported that they were well or moderately motivated. However, the librarians differ significantly on how far they were motivated. It was found out that majority of the librarians performed poorly in their expected tasks while very few perform very highly. This has confirmed Ugwoegbu's (2007) view that there is laxity among librarians in academic libraries in Nigeria. Librarians serve library users, as the library is service oriented. With the poor task performance revealed in this study, the assertion of Robert (2003) that library users find it difficult to make use of the library because they are not properly handled is confirmed.

According to Obunadike (2008) motivation plays a vital role in task performance. This study did not agree wholly with the assertion. It also disagrees with the claim of Mullins (1996) that increase in the motivation of workers will lead to an increase in their task performance.

The insignificant positive relationship existing between the librarians' level of motivation and their task performance could be due to the fact that a good number of them indicated that they are being poorly motivated. Although the librarians are not well motivated, with their interest on the profession, they have the zeal to still perform well in their tasks. The interest on the profession is a sort of intrinsic motivation which is the propelling factor for the moderate and high level of task performance. This category of the librarians do not wait to be motivated by anybody. They motivate and engineer themselves to appreciable level of task performance. They love the profession of librarianship and the job they do.

\section{Conclusion}

This study concludes that the librarians in the university libraries studied are poorly motivated by the managements of the different universities. This notwithstanding majority of them performs moderately on their basic tasks in the libraries. The intrinsic motivation and love for library profession propel this greater majority of academic librarians in the university libraries to put in their best on their job. This group of librarians believe that with or without extrinsic motivation by the management, they must do their work to the best of their abilities and satisfy their conscience. The researchers assert that this informed the no correlation existing between the librarians' levels of motivation and their task performance. The finding of this study will not serve as an excuse by the university management not to motivate librarians in the universities appropriately. The insignificant number of librarians in the university libraries who are also not adequately motivated face their work with high level of laxity. This has equally affected some of the library users, as they are not using the library effectively, as reported in some earlier studies reviewed. Both intrinsic and extrinsic motivations have their own part to play in task performance by librarians in university libraries. To get the best services from all librarians in university libraries, as most librarians do their part without looking for extrinsic motivation, the management of universities should always do their part by giving all the librarians adequate motivation. This will also encourage the very few of the librarians who are expecting it to also give their best in their task performance.

\section{References}

[1] Akor, Philip U. (2010) Motivation as acorrelate to job performance of profession librarians in the university libraries in Markudi, Benue state. Unizik journal of research in library and information science.2 (1):54-64

[2] Ike, Adedimpe (2007) Whither Nigerian Librarianship: an invited paper to the Anambra State chapter of the Nigerian Library Association. Anambra state Library And Information Science Digest.1 (1): 5-18

[3] Mullins, L (1996) Management and organization-4 $4^{\text {th }}$ ed. London: Pitman Nigeria: Federal Government (2004). National Policy on Education. Abuja: Government Press

[4] Nwamefor, Ralph (2007). Sensitizing the South-East zone librarians of the Nigerian Library Association. Anambra State library and Information Science Digest. 1 (1): 25-30

[5] Nwosu, Obiora Chukwuma (2008) Apathy in the Library and Information Science Profession in Anambra state, Nigeria. Anambra State Library and Information Science Digest. 1(2):8-15

[6] Ogbunadike, J.C (2008). Effective Motivation of teachers for the attainment of Millennium development goals. In B.G. Nworgu-ed (2008) Education in the age of Global challenge and enhancement strategies. Nsukka: University of Nigeria: UTP 468-469

[7] Robert, D.B (2003). Why measure performance? Different purposes require different measures. American society for Public Administration. 63(5):586-606

[8] Ugwoegbu, F (2007) Strategies for minimizing theft in academic libraries. Journal of Adult Education studies. 2(2):67-69 